\title{
PENGARUH LATIHAN PLIOMETRIK STANDING LONG JUMP (BROAD JUMP) DAN STANDING JUMP TERHADAP LOMPAT JAUH GAYA GANTUNG ATLET ATLETIK LOMPAT JAUH PROVINSI BENGKULU DI PPLP BENGKULU
}

\author{
Acen Yukarda \\ email : acen.ay34@gmail.com \\ Universitas Bengkulu \\ Dian Pujianto \\ Universitas Bengkulu \\ Arwin \\ Universitas Bengkulu
}

\begin{abstract}
Abstrak
Penelitian ini bertujuan untuk mengetahui pengaruh latihan pliometrik standing long jump (broad jump) dan standing jump terhadap lompat jauh gaya gantung atlet atletik provinsi Bengkulu di PPLP Bengkulu. Lompat jauh adalah olahraga yang mengabungkan kecepatan, kekuatan, kelenturan, daya tahan, power, dan ketepatan. Metode yang digunakan dalam penelitian ini adalah metode eksperimen dan menggunakan desain One-Group Pretestposttes Desing. Penelitian ini dilaksanakan di PPLP Provinsi Bengkulu terpatnya dilapangan PPLP Provinsi Bengkulu. Teknik Pengumpulan data dalam penelitian ini adalah tes lompat jauh gaya gantung. Sampel dalam penelitian ini atlet atletik lompat jauh Provinsi Bengkulu di PPLP Provinsi Bengkulu yang berjumblah 12 orang dibagi menjadi 2 kelompok perlakuan, dengan teknik sampling purposive. Analisis data dalam penelitian ini menggunakan $t$-test. Berdasarkan hasil perhitungan statistik hasil uji-t kelompok eksperimen 1 diperoleh $t_{\text {hitung }}$ sebesar 4.328 lebih besar dari $t_{\text {tabel }}$ sebesar 2.571 dan taraf singnifikan $5 \%$, Sedangkan kelompok eksperimen 2 diperoleh thitung sebesar 4.284 lebih besar dari tabel sebesar 2.571 dan taraf singnifikan 5\%. Hal ini menunjukan adanya peningkatan sebelum dan sesudah diberikannya perlakuan sehinga hipotesis penelitian ini Ha diterima dan Ho ditolak. Sehinga dapat disimpulkan bahwa latihan pliometrik standing long jump (broad jump) dan standing jump dapat meningkatkan prestasi lompat jauh gaya gantung.
\end{abstract}

Kata kunci: Pliometrik, Standing Long Jump (Broad Jump), Lompat Jauh, Gaya Gantung

\begin{abstract}
This study aims to determine the effect of pliometric exercise standing long jump (broad jump) and standing jump against long jump style hanging athletic athletes of Bengkulu province in PPLP Bengkulu. Long jump is a sport that combines speed, strength, flexibility, endurance, power, and precision. The method used in this study is the experimental method and using the design of One-Group Pretest-posttes Desing. This research was conducted in PPLP of Bengkulu Province in PPLP field in Bengkulu Province. Techniques Data collection in this study is a long jump style test. The sample in this study athletic athletes long jump Bengkulu Province in PPLP Bengkulu Province which bertumblah 12 people divided into 2
\end{abstract}


groups of treatment, with purposive sampling technique. Data analysis in this research use $t$ test. Based on the result of statistical calculation result of t-test of experiment group 1 obtained t count equal to 4,328 bigger than ttabel equal to 2,571 and 5\% significant level, while experiment group 2 obtained titung equal to 4,284 bigger than ttable equal to 2,571 and 5\% significant level. This indicates an increase before and after the given treatment so that this research hypothesis $\mathrm{Ha}$ accepted and Ho rejected. So it can be concluded that pliometric exercise standing long jump (broad jump) and standing jump can improve the achievement of long jump style.

\section{Keywords: Plyometrics, Standing Long Jump (Broad Jump), Long Jump, Hanging Style}

\section{PENDAHULUAN}

Cabang olahraga atletik merupakan olahraga tertua di dunia dan sering disebut dengan sebutan Mother of Sport yaitu ibu atau induk dari olahraga. Hal tersebut karena di dalam olahraga atletik mengandung unsur yang paling dasar di dalam kehidupan manusia yaitu, lari, lempar, lompat, dan jalan hal ini merupakan komponen dari gerak dasar dari semua cabang olahraga, sehingga atletik di katakan sebagai ibu dari semua olahraga.

Terlepas dari itu olahraga merupakan bagian dari aktivitas sehari-hari manusia yang berguna untuk jasmani dan rohani yang sehat, olahraga juga merupakan kegiatan yang menyenangkan. Selain sebagai kegiatan rekreasi, olahraga juga memberi energi yang positif dan nyata bagi peningkatan kesehatan masyarakat. Manusia dalam melaksanakan kegiatan olahraga merupakan salah suatu kebutuahn yanga harus dipenuhi walaupuan tujuan dan alasan manusia dalam melakukan kegiatan olahraga berbedabeda, dilihat dari alasan dan tujuan manusia melakukan kehiatan olahraga pada saat ini antara lain: 1) melakukan kegiatan olahraga untuk rekreasi, 2) melakukan kegiatan olahraga untuk mencapai tujuan pendidikan, 3) melakukan kegiatan olahraga untuk penyembuhan penyakit dan pemulihan penyakit, 4) melakukan kegiatan olahrga untuk prestasi yang setinggi-tingginya.

Salah satu cabang olahraga yang dapat meningkatkan prestasi adalah cabang olahraga atletik, salah satunya yaitu, lompat jauh. Lompat jauh adalah salah satu cabang olahraga yang mengandalkan kecepatan yang luar biasa, kekuatan, kelenturan, daya tahan yang tinggi, daya ledak, ketepatan, dan otot yang sangat kuat.

Lompat jauh merupakan perlombaan dimana perserta atau jumper mengambil ancangancang lebih kurang sejauh 30 meter dari garis lompat, kemudian mempercepat langkah kakinya sampai kecepatan maksimum sebelum melakukan tolakan (meloncat) dengan satu kaki sedekat mungkin dari tepian garis lompat, kemudian melayang di udara dan mendarat sejauh-jauhnya dalam bak pasir.

Menurut pengamatan yang sedang peneliti lakukan, pada umumnya atlet atletik provinsi bengkulu memiliki lompatan yang sudah baik dengan ditunjang dengan adanya atlet atletik bengkulu berkiprah di ajang perlombaan nasional seperti: O2SN, JURNAS, JURNAS junior. Namun pada faktanya prestasi atletik khususnya di nomor lompat jauh mengalami kemunduran, terutama lompat jauh gaya gantung yang prestainya masih rendah dan jarang digunakan pada saat perlombaan, dan juga menurut pengamatan peneliti dalam hal ini terlihat kurangnya latihan kekuatan otot tungkai dan daya ledak ledak yang merupakan unsur yang menopang untuk nomor lompat, terutama latihan dalam bentuk pliometrik standing long jump (broad jump) dan standing jump. Hal ini terlihat dari tahun 2016 dan 2017 tidak ada atlet atletik lompat jauh bengkulu meraih mendali.

Sehingga peneliti sangat tetarik untuk meneliti tentang "Pengaruh Latihan Pliometrik Standing Long Jump (Broad jump ) dan Standing Jump Terhadap Lompat Jauh Gaya Gantung Atlet 
Atletik Lompat Jauh Provinsi Bengkulu di PPLP Bengkulu".

\section{RUMUSAN MASALAH}

Berdasarkan dari batasan masalah pada atlet atletik lompat jauh provinsi Bengkulu di PPLP Bengkulu, maka dalam penelitian ini masalah tersebut akan dirumuskan pada rumusan masalah sebagai berikut: "Apakah ada pengaruh latihan pliometrik standing long jump (broad jump) dan standing jump terhadap kemampuan lompat jauh gaya gantung atlet atletik lompat jauh Provinsi Bengkulu di PPLP Bengkulu ?".

\section{METODE PENELITIAN}

Penelitian ini merupakan penelitian eksperimen yang bertujuan untuk mencari pengaruh perlakuan latihan pliometrik standing long jump (broad jump) dan standing jump terhadap lompat jauh gaya gantung atlet atletik lompat jauh Provinsi Bengkulu di PPLP Bengkulu.

Adapun desain penelitian yang peneliti gunakan adalah One-Group Pretest-posttest Design, peneltian ini membandingkan hasil pre test dan post test sebelum dan sesudah diberikan perlakuan. Penelitian ini dilaksanakan kurang lebih satu bulan sebanyak 16 kali pertemuan. Tepatnya pada tanggal 09April-2018 hingga 09 juli 2018.

Dalam penelitian ini sampel penelitian yang digunakan adalah Metode sampling purposive, makan sampel dalam penelitian ini adalah atlet atletik lompat jauh provinsi Bengkulu di PPLP Bengkulu yang berjumlah 12 orang yaitu 5 putri dan 7 putra. Kemudian di bagi menjadi dua kelompok perlakuan yaitu untuk kelompok eksperimen 1 adalah standing long jump (broad jump) dan untuk kelompok eksperimen 2 adalah standing jump.

Untuk mendapatkan data yang dibutuhkan dalam penelitian ini yang merupakan alat bantu bagi peneliti dalam menggumpulkan data yaitu dengan tes, Maka alat pengumpulan data dalam penelitian ini yang bermaksud mengumpulkan data penelitian adalah data tes awal (pre test) dan tes akhir (post test) lompat jauh gaya gantung. Instrumen penelitian yang digunakan dalam penelitian ini adalah lompat jauh gaya gantung.

Dalam penelitian ini peneliti melakukan tes dengan instrumen yang digunakan memiliki angka validitas sebesar 0,998 dan reabilitas sebesar 0,998 untuk hasil akhir.

Teknik analisis data dalam penelitian ini mengunakan $u j i-t$ ( $t-$ test $)$. Dengen demikian langkah-langkah analisis data eksperimen dengan model One-Group pre-test post-test Desing. Teknik analisis data yang digunakan dalam penelitian ini pertama dilakukan uji normalitas data. Kemudian dilakukan uji homogenitas varians. Lalu uji hipotesis. Yaitu untuk mengetahui apakah ada pengaruh latihan pliometrik standing long jump (broad jump) dan standing jump terhadap kemampuan lompat jauh gaya gantung atlet atletik lompat jauh Provinsi Bengkulu di PPLP Bengkulu.

\section{HASIL PENELITIAN DAN PEMBAHASAN Hasil Penelitian}

Data tes awal diambil pada tanggal 10 April 2018 dan data tes akhir pada tanggal 19 Mei 2018. Perlakuan (Treatment) dilakukan 16 kali pertemuan dengan frekuensi latihan 3 (tiga) kali pertemuan dalam satu minggu, yaitu Senin, kamis, dan Sabtu. Pengumpulan data mengunakan tes lompat jauh gaya gantung baik tes awal (pre-test) maupun tes akhir (post-test) dengan melakukan lompatan layaknya seperti pada saat perlombaan sebanyak 7 kali kesempatan, kemudian diambil nilai terbaik atau jarak lompatan terjauh.

Dengan demikian diperoleh data dalam melakukan tes lompat jauh gaya gantung pada saat tes awal (pre test) dan tes akhir (post test) sebagai berikut:

\section{Kelompok Eksperimen 1 Standing long Jump (broad jump)}

Tabel 1. Hasil Tes Awal (pre test) dan Tes Akhir (post test) Lompat Jauh Gaya Gantung Kelompok Eksperimen Standing Long Jump (broad Jump)

\begin{tabular}{l|l|l|l|} 
No & Tes & Tes & Selisih \\
Awal & Akhir & \\
pre- & post- \\
test & test & \\
cm) & (cm) &
\end{tabular}




\begin{tabular}{l|l|l|l}
1 & 546 & 568 & 22 \\
\hline 2 & 442 & 492 & 50 \\
\hline 3 & 438 & 484 & 46 \\
\hline 4 & 537 & 548 & 11 \\
\hline 5 & 490 & 506 & 16 \\
\hline 6 & 502 & 527 & 25 \\
\hline Rata-rata & 492.5 & 520.83 & 27.83 \\
\hline Simpangan Baku & 45.74 & 32.89 & 12.85 \\
\hline Nilai Minimal & 438 & 484 & 46 \\
\hline Nila Maksimal & 546 & 568 & 22
\end{tabular}

Berdasarkan pada tabel 1 diatas di dapat hasil tes awal (pre test) kelompok eksperimen standing long jump (broad jump) didapatkan hasil sebagai berikut : Diperoleh nilai rata-rata $=492,5$ simpangan baku $=45,74$, nilai maksimal $=546$, nilai minimal $=438$, sedangkan tes akhir (posttest) kelompok eksperimen standing long jump (broad jump) sebagai berikut : Diperoleh nilai rata-rata $=520.83$, simpangan baku $=32.89$, nilai maksimal $=568$, dan nilai minimal $=484$

Tabel 2. Deskripsi Statistik Pre Test dan Post Test Lompat Jauh Gaya Gantung Kelompok Eksperimen Standing Long Jump (Broad Jump)

\begin{tabular}{l|l|l|l|l|l|l} 
No & $\begin{array}{l}\text { Hasil } \\
\text { Raiha } \\
\text { n }\end{array}$ & Katago & \multicolumn{2}{|l|}{ Pre-test } & \multicolumn{2}{l}{ Post-test } \\
\cline { 4 - 7 } & $>495$ & $\begin{array}{l}\text { Baik } \\
\text { Sekali }\end{array}$ & 3 & $50 \%$ & 4 & $\begin{array}{l}66.67 \\
\%\end{array}$ \\
\hline 1 & $\begin{array}{l}463- \\
494\end{array}$ & Baik & 1 & $\begin{array}{l}16.67 \\
\%\end{array}$ & 2 & $\begin{array}{l}33.33 \\
\%\end{array}$ \\
\hline 3 & $\begin{array}{l}449- \\
462\end{array}$ & Sedang & 0 & $0 \%$ & 0 & $0 \%$ \\
\hline 4 & $\begin{array}{l}424- \\
448\end{array}$ & Kurang & 2 & $\begin{array}{l}33.33 \\
\%\end{array}$ & 0 & $0 \%$ \\
\hline 5 & $<423$ & $\begin{array}{l}\text { Kurang } \\
\text { sekali }\end{array}$ & 0 & $0 \%$ & 0 & $0 \%$ \\
\hline $\begin{array}{l}\text { Jumla } \\
\text { h }\end{array}$ & & & 6 & $100 \%$ & 6 & $100 \%$ \\
\hline
\end{tabular}

Berdasarkan pada tabel 2 diatas dapat kita lihat hasil tes sebelum dan sesudah perlakuan mengalami peningkatan, dari 2 atlet dikatagorikan kurang menjadi 0 atlet dan dikatagorikan baik 1 atlet menjadi 2 atlet kemudian untuk yang dikatagorikan sangat baik dari semulanya 3 atlet menjadi 4 atlet. Jelas terlihat dari hasil pre-test dan kemudian diberi perlakuan selanjutnya dilakukan post-test

mengalami peningkatan yang signifikan dan banyak dikatagorikan sangat baik.

\section{Kelompok Eksperimen 2 Standing Jump}

Tabel 3. Hasil Tes Awal (pre tast) dan Tes Akhir (post test) Lompat Jauh Gaya Gantung Kelompok Eksperimen Standing Jump

\begin{tabular}{l|l|l|l} 
No & $\begin{array}{l}\text { Tes } \\
\text { Awal } \\
\text { pre-test } \\
(\mathrm{cm})\end{array}$ & $\begin{array}{l}\text { Tes Akhir } \\
\text { post-tes } \\
\text { (cm) }\end{array}$ & Selisih \\
\hline 1 & 420 & 478 & 58 \\
\hline 2 & 368 & 432 & 64 \\
\hline 3 & 504 & 532 & 28 \\
\hline 4 & 556 & 588 & 32 \\
\hline 5 & 528 & 550 & 22 \\
\hline 6 & 428 & 440 & 12 \\
\hline Rata-rata & 467.33 & 503.33 & 36 \\
\hline $\begin{array}{l}\text { Simpangan } \\
\text { Baku }\end{array}$ & 72.56 & 63.10 & 9.46 \\
\hline $\begin{array}{l}\text { Nilai } \\
\text { Terendah }\end{array}$ & 368 & 432 & 64 \\
\hline Nilai Tertinggi & 556 & 588 & 32
\end{tabular}

Berdasarkan pada tabel 3 diatas di dapat hasil awal (pre test) kelompok eksperimen standing jump didapatkan hasil sebagai berikut : Diperoleh nilai rata-rata $=467.33$ simpangan baku $=72.86$, nilai tertinggi $=556$, nilai terendah $=368$, sedangkan tes akhir (post test) kelompok eksperimen standing jump sebagai berikut : Diperoleh nilai rata-rata $=503.33$, simpangan baku $=63.10$, nilai tertinggi $=588$, dan nilai terendah $=432$

Tabel 4. Deskripsi Statistik Pre Test dan Post Test Lompat Jauh Gaya Gantung Kelompok Eksperimen Standing Jump

\begin{tabular}{|c|c|c|c|c|c|c|}
\hline \multirow[t]{2}{*}{ No } & \multirow{2}{*}{$\begin{array}{l}\text { Hasil } \\
\text { Raiha } \\
\text { n }\end{array}$} & \multirow{2}{*}{$\begin{array}{l}\text { Katago } \\
\text { ri }\end{array}$} & \multicolumn{2}{|c|}{ Pre-test } & \multicolumn{2}{|c|}{ Post-test } \\
\hline & & & $F$ & $\%$ & $f$ & $\%$ \\
\hline 1 & $>495$ & $\begin{array}{l}\text { Baik } \\
\text { Sekali }\end{array}$ & 3 & $50 \%$ & 3 & $50 \%$ \\
\hline 2 & $\begin{array}{l}463- \\
494\end{array}$ & Baik & 0 & $0 \%$ & 1 & $\begin{array}{l}16.67 \\
\%\end{array}$ \\
\hline 3 & $\begin{array}{l}449- \\
462\end{array}$ & Sedang & 0 & $0 \%$ & 0 & $0 \%$ \\
\hline 4 & $\begin{array}{l}424- \\
448\end{array}$ & Kurang & 1 & $\begin{array}{l}16.67 \\
\%\end{array}$ & 2 & $\begin{array}{l}33.33 \\
\% \\
\end{array}$ \\
\hline 5 & $<423$ & $\begin{array}{l}\text { Kurang } \\
\text { sekali }\end{array}$ & 2 & $\begin{array}{l}33.33 \\
\%\end{array}$ & 0 & $0 \%$ \\
\hline $\begin{array}{l}\text { Jumla } \\
\text { h }\end{array}$ & & & 6 & $100 \%$ & 6 & $100 \%$ \\
\hline
\end{tabular}


Berdasarkan pada tabel 4 diatas dapat kita lihat hasil tes sebelum dan sesudah perlakuan mengalami peningkatan, dari 2 atlet dikatagorikan kurang sekali menjadi 0 atlet dan dikatagorikan baik sebelumnya 0 atlet menjadi 1 atlet kemudian untuk yang dikatagorikan sangat baik dari semulanya 3 atlet tetap sama 3 atlet. Jelas terlihat dari hasil pre-test dan kemudian diberi perlakuan selanjutnya dilakukan post-test mengalami peningkatan yang signifikan dan banyak dikatagorikan sangat baik.

Uji Normalitas

a) Uji Normalitas Tes Awal (Prie-test) Kelompok Eksperimen Standing Long Jump (Broad Jump) dan Standing Jump

Tabel 5. Hasil Perhitungan Uji Normalitas Tes Awal (Pre-Test)

\begin{tabular}{l|l|l|l} 
Kelompok & $L_{\text {hitung }}$ & $L_{\text {tabel }}$ & Kriteria \\
\hline $\begin{array}{l}\text { Eksperimen } \\
\text { Standing Long } \\
\text { Jump(broad jump) }\end{array}$ & 0.1986 & 0.319 & Normal \\
\hline $\begin{array}{l}\text { Eksperimen } \\
\text { Standing Jump }\end{array}$ & 0.2054 & & Normal
\end{tabular}

Berdasarkan Tabel 5 menunjukan bahwa kelompok eksperimen standing long jump dan kelompok eksperimen standing jump sebelum diberi perlakuan berdistribusi normal. Hal ini ditunjukan dari hasil perhitungan yang menunjukan bahwa data penelitian memiliki nilai $L_{\text {hitung }}<L_{\text {tabel, }}$ yang mana nilai $L_{\text {hitung, }}$ kelompok eksperimen standing long jump adalah sebesar 0.1986 , dan < Ltabel yang sebesar 0.319, dan Lhitung kelompok eksperimen standing jump adalah sebesar 0.2054, dan < Ltabel yang sebesar 0.319. Perhitungan $\mathrm{L}^{2}$ hitung $<\mathrm{L}^{2}$ tabel maka data awal (pre-tast) kelompok eksperimen standing long jump (broad jump) dan kelompok eksperimen standing jump berdistribusi normal.

\section{b) Uji Normalitas Tes Akhir (Post-test) Kelompok Eksperimen Standing Long Jump (Broad Jump) dan Standing Jump}

Tabel 6. Hasil Perhitungan Uji Normalitas Data Akhir (post-test)

\begin{tabular}{l|l|l|l} 
Kelompok & $L_{\text {hitung }}$ & $L_{\text {tabel }}$ & Kriteria \\
\hline Eksperimen & 0.1740 & 0.319 & Normal
\end{tabular}

\begin{tabular}{|l|l|}
$\begin{array}{l}\text { Standing Long } \\
\text { Jump(Broad Jump }\end{array}$ & \\
\hline $\begin{array}{l}\text { Eksperimen } \\
\text { Standing Jump }\end{array}$ & $\mathbf{0 . 1 8 5 3}$ \\
\hline
\end{tabular}

Normal

Berdasarkan Tabel 6 menunjukan bahwa kelompok eksperimen standing long jump (broad jump) dan kelompok eksperimen standing jump sebelum diberi perlakuan berdistribusi normal. Hal ini ditunjukan dari hasil perhitungan yang menunjukan bahwa data penelitian memiliki nilai $L_{\text {hitung }}<L_{\text {tabel, }}$ yang mana nilai $L_{\text {hitung, kelompok }}$ eksperimen standing long jump adalah sebesar 0.1740 , dan $<$ Ltabel yang sebesar 0.319 , dan Lhitung kelompok eksperimen standing jump adalah sebesar 0.1853 , dan < Ltabel yang sebesar 0.319. Perhitungan $L^{2}$ hitung $<L^{2}$ tabel maka data awal (pre-tast) kelompok eksperimen standing long jump (broad jump) dan kelompok eksperimen standing jump berdistribusi normal.

\section{Uji Homogenitas}

Tabel 7. Hasil Perhitungan Homogenitas Kelompok Eksperimen Standing Long Jump (broad jump) dan Eksperimen Standing Jump

\begin{tabular}{|c|c|c|c|c|}
\hline Kelompok & $F_{\text {hitung }}^{2}$ & DK & $F_{\text {tabel }}^{2}$ & Kriteria \\
\hline $\begin{array}{l}\text { Eksperimen } \\
\text { Standing } \\
\text { Long Jump } \\
\text { (Broad Jump) }\end{array}$ & 1.391 & 5 & 5.05 & Homogen \\
\hline $\begin{array}{l}\text { Eksperimen } \\
\text { Standing } \\
\text { Jump }\end{array}$ & 1.155 & 5 & & Homogen \\
\hline
\end{tabular}

Berdasarkan Tabel 7 menunjukan bahwa kelompok eksperimen 1 dan kelompok eksperimen 2 berdistribusi homogen. Dari tabel diatas dapat dilihat untuk kelompok eksperimen 1 didapatkan hasil $F_{\text {hitung }}<=1.391<F_{\text {tabel }}=5.05$ dan untuk kelompok eksperimen 2 didapatkan hasil $F_{\text {hitung }}<=1.155<\mathrm{F}_{\text {tabel }}=5.05$ sehingga dapat di simpulkan tidak terdapat perbedaan dari masing-masing variabel kelompok eksperimen standing long jimp (broad jump) dan standing jump atau harga variansnya Homogen.

\section{Uji Hipotesis}

Tabel 8. Hasil Perhitungan Uji Hipotesis Kelompok Eksperimen Standing Long Jump (Broad jump) dan Eksperimen Standing Jump 


\begin{tabular}{l|l|l|l|l} 
Kelompok & $t_{\text {hitung }}$ & DK & $t_{\text {tabel }}$ & Kriteria \\
\hline $\begin{array}{l}\text { Eksperimen } \\
\text { Standing } \\
\text { Long Jump } \\
\text { (Broad Jump) }\end{array}$ & 4.323 & 5 & 2.571 & Signifikan \\
\hline $\begin{array}{l}\text { Eksperimen } \\
\text { Standing } \\
\text { Jump }\end{array}$ & 4.284 & 5 & & Signifikan \\
\cline { 2 - 3 } & & & &
\end{tabular}

Jadi berdasarkan hasil perhitungan posttest naik secarah signifikan bila dibandingkan dengan hasil pre-test hal ini menunjukan perlakuan telah diberikan dan dilaksanakan secarah efektif sehingga berhasil meningkatkan pertasi para atlet atletik lompat jauh. Hal ini ditunjukan dari hasil perhitungan yang menunjukan bahwa data penelitian memiliki nilai $F_{\text {hitung }}>F_{\text {tabel }}$ dimana hasil perhitungan kelompok eksperimen standing long jump (broad jumb) $F_{\text {hitung }}=4.328>F_{\text {tabel }}=2.571$ berarti singnifikan dan kelompok ekperimen standing jump sebesar $F_{\text {hitung }}=4.284>F_{\text {tabel }}=2.571$ berarti singnifikan. Jadi dapat kita tarik kesimpulan bahwa kedua kelompok ekperimen naik secarah signifikan sebelum dan sesudah diberi perlakuan.

\section{PEMBAHASAN}

Berdasarkan perhitungan data kelompok eksperimen 1 standing long jump (broad jump) dan eksperimen 2 standing jump dapat kita lihat bahwa kedua kelompok eksperimen mengalami peningkatan secarah signifikan sehingga para atlet atletik lompat jauh Provinsi Bengkulu di PPLP Bengkulu mengalami peningkatan prestasi lompatan yaitu, lompat jauh gaya gantung. Hal tersebut terlihat bahwa rata-rata disetiap kelompok eksperimen mengalami peningkatan, untuk kelompok eksperimen 1 standing long jump (broad jump) hasil rata-rata tes awal (pretest) sebesar 492,5 dan hasil rata-rata tes akhir (post-test) sebesar 520,83 dan memiliki selisih 28,33. Untuk kelompok eksperimen 2 standing jump hasil rata-rata tes awal (pre-test) sebesar 467,33 dan hasil rata-rata tes akhir (post-test) sebesar 503.33 dan memiliki selisih 36 .

Melihat pada hasil analisis data yang diperoleh dari penelitian pada kelompok eksperimen 1 standing long jump (broad jump) dan kelompok eksperimen 2 standing jump diperoleh nilai $t_{\text {hitung }}$ yang lebih besar jika dibandingkan dengan nilai $t_{\text {tabel }}$ yang berarti terdapat pengaruh yang signifikan.

Melihat hasil perhitungan uji-t antara hasil tes akhir kelompok eksperimen 1 standing long jump (broad jump) dan kelompok eksperimen 2 standing jump yang menunjukan nilai $t_{\text {hitung }}$ lebih besar dari pada $t_{\text {tabel }}$ maka dengan hal tersebuat dapat dikatakan bahwa kelompok eksperimen 1 standing long jump (broad Jump) dan kelompok eksperimen 2 standing jump, jika dibandingkan dengan tes awal sebelum diberi perlakuan latihan menunjukan bahwa pemberian latihan pliometrik standing long jump (broad jump) dan standing jump memberikan peningkatan prestasi pada hasil lompatan lompat jauh gaya gantung.

Hal tersebut didasarkan pada teori yang digunakan peneliti dalam penyusunan penelitian ini, latihan pliometrik menurut Donal A. Chu (1992 : 1). Bahwa latihan pliometrik adalah latihan yang dilakukan dengan sengaja untuk meningkatkan kemampuan atlet, yang merupakan perpaduan latihan kecepatan dan kekuatan. Sehingga latihan dalam bentuk pliometrik tersebut mempengaruhi hasil lompat jauh gaya gantung atlet atletik lompat jauh Provinsi Bengkulu di PPLP Bengkulu terutama lompat jauh gaya gantung.

Dengan diberikannya program latihan pliometrik untuk setiap kelompok eksperimen dapat dilihat dari hasil program latihan yang diberikan menunjukan adanya peningkatan prestasi lompatan atlet atletik lompat jauh Provinsi Bengkulu di PPLP Bengkulu. Dilihat dari rata-rata dan analisis data di atas, maka latihan pliometrik standing long jump (broad jump) dan standing jump berpengaruh terhadap peningkatan prestasi lompat jauh, jadi dapat dikatakan bahwa latihan pliometrik dalam bentuk standing long jump (broad jump) dan standing jump dapat digunakan sebagai salah satu bentuk latihan untuk meningkatkan prestasi atlet atletik lompat jauh terutama lompat jauh gaya gantung.

Dalam memberikan program latihan pliometrik, peneliti memberikan latihan dengan berbagai macam variasi dan peningkatan, yang bertujuan para atlet dapat berlatih dengan gembira dan tidak mengalami kejenuhan, 
tentunya mengalami kemajuan serta latihan tidak menjadi monoton.

Secarah keseluruhan dapat dikatakan bahwa hipotesis penelitian $\mathrm{Ha}$ diterima dan $\mathrm{Ho}$ ditolak sehinga terjawab permasalahan serta mencapai tujuan dari penelitian ini. Penentuan populasi, sampel, variabel dan pelaksanaan kegiatan penelitian seperti tes awal, pelaksanaan latihan dan tes akhir kesemuannya didasarkan pada teori dan aturan yang ada sehingga memberikan dasar yang baik pada penelitian ini. Penentuan metode, instrumen dan langkah penelitian serta pelaksanaan analisis dan pemilahan alat analisis sudah terbukti dan benar serta memberikan hasil yaitu tercapainya tujuan penelitian yang dilaksanakan ini.

\section{SIMPULAN DAN SARAN}

\section{Simpulan}

Berdasarkan pembahasan dan penelitian yang telah di dibawa, maka dapat diambil simpulan bahwa :

1. Latihan pliometrik standing long jump (broad jump) berpengaruh terhadap lompat jauh gaya gantung atlet atletik lompat jauh Provinsi Bengkulu di PPLP Bengkulu.

2. Latihan pliometrik standing jump berpengaruh terhadap lompat jauh gaya gantung atlet atletik lompat jauh Provinsi Bengkulu di PPLP Bengkulu.

\section{Saran}

Saran yang dapat diberikan peneliti dengan hasil penelitian ini antara lain sebagai berikut :

1. Sebaiknya pelatih atau pun guru pendidikan jasmani dalam melakukan latihan lompat jauh mengunakan variasi latihan, salah satunya dalam bentuk latihan pliometrik, karena terbukti latihan dalam bentuk pliometrik dapat memberikan hasil lompatan yang lebih baik ketika atlet diberi latihan dalam bentuk pliometrik.

2. Untuk para atlet atau pun siswa senantiasa meningkatkan prestasi dengan latihan yang tekut dan semangat dan juga senatiasi melakukan latihan dalam bentuk pliometrik dalam meningkatkan prestasi yang lebih baik lagi.
3. Bagi peneliti yang ingin melanjutkan penelitian ini agar dapat menjadikan penelitian ini sabagai bahan informasi dan dapat melanjutkan penelitian dengan populasi dan sampel yang berbeda dan tentunya dalam jumlah yang lebih banyak lagi.

\section{DAFTAR PUSTAKA}

Djumidar, (2015). Dasar-dasar Atletik. Jakarta : Universitas Terbuka

Manuel Jose Ballesteros, (1993). Pedoman Dasar Melatih Atletik. Stadion Madya : PASI \& IAAF.

Pitria, Tono, dan Arwin. 2019. "Perbedaan Pengaruh Latihan Pliometrik Single Leg Speed Hop dan Double Leg Speed Hop Terhadap Kemampuan Lompat Jauh Gaya Jongkok Di SMA Negeri 08 Bengkulu Utara”. Jurnal Kinestetik, Vol. 3 (1).

Suharno, (1993). Metode Pelatihan. Jakarta : Koni Pusat.

Sugiyono,(2011). Metode Penelitian Kuantitatif, Kualitatif dan $R \& D$. Bandung : Alfabeta.

Widiastuti, (2001). Tes dan Pengukuran Olahraga. Jakarta : PT Bumi Timur Jaya. 